Krenkel and many other non-Egyptian geologists (i.e. geologists who did not work in Egypt for many years) who developed theories on the Red Sea graben without knowing in detail the stratigraphy and structural features of Egypt.

Once again, a less emotional approach in future would help to improve international relations amongst geologists.

DR. S. W. TROMP,

Geological Consultant, United Nations Techn. Ass. Adm.

RIJNSBURGERWEG 159 ,

LEIDEN.

4th June 1951

SIR,-I am much relieved to learn that Dr. Tromp has not overlooked the work of the Geological Survey of Egypt and that it is to receive due recognition in his forthcoming publication. My letter, however, referred necessarily to his published paper. If I was guilty of emotion, it was indignation, because in his paper Dr. Tromp attributed to himself a number of discoveries for which the credit belongs elsewhere.

SedgWick Museum,

W. J. Arkell.

CAMBRIDGE.

10th June, 1951.

\title{
SCOURIE DYKES AND LAXFORDIAN METAMORPHISM
}

SIR,-In his paper "Scourie Dykes and Laxfordian Metamorphism" (Geol. Mag., lxxxviii, 153) Sir Edward Bailey makes a number of severe comments based on abstracts of papers presented by us to the Geological Society (Abstr. Proc. Geol. Soc., 1950, 51-3) concerning parts of the Lewisian of Scotland. These comments amount to a statement, firstly, that we had failed to acknowledge our debt to the great body of knowledge built up by previous workers and set out principally in the North-West Highland Memoir of 1907 , and secondly, that we have produced neither new material nor new ideas.

The papers (which are now in the press and will appear as one paper in the Q.J.G.S., cvi, 1951) begin with what we hope is an adequate outline of earlier work. We refer therein specifically to the pages of the North-West Highland Memoir dealing with the Torridon and Scourie areas now in question. When the papers were delivered, care was taken to give the substance of the quotations and references with which our paper opens and to outline the present state of knowledge of the two areas.

It is unfortunate that, as Sir Edward Bailey was not present at the meeting, and because the paper has not yet been published, his knowledge of its contents appears to be confined to what was set out in the printed abstracts. The manuscripts were deposited in August, 1949, with the Geological Society, where they were available for consultation on application. Had we known that Sir Edward Bailey held such strong views on the abstracts we should ourselves have been happy to send him a copy of the complete manuscript.

The prevalent conception of the Lewisian has been epitomized by Peach and Horne (Chapters on the Geology of Scotland, 1930, p. 24). They write : "The detailed mapping of that region [the western seaboard of Ross and Sutherland] by the Geological Survey has shown that the rocks are divisible into (1) a Fundamental Complex, consisting mainly of gneisses that have affinities, both chemically and mineralogically, with plutonic igneous products, and partly of crystalline schists which are evidently of sedimentary origin; (2) a series of igneous rocks intrusive in that complex in the form of dykes, sills, and irregular veins."

Sir Edward has recently written of our Abstracts : "Like the authors of these summaries, I agree with the bulk of the striking results set out by Teall and his colleagues." We cannot, however, agree with such a complete correlation of our opinion with that of the authors of the Memoir of 1907. Thus, we reject the view that the complex is mainly orthogneiss; we reject 
the implication that the present chemical and mineralogical state of the gneiss necessarily bears on its original nature; we reject the classification itself. Not until we read Sir Edward Bailey's recent paper did we understand how his misconception of our position arose. On p. 157 he writes : " the Fundamental Complex (which they [Sutton and Watson] call Scourian, I prefer Assynt ....)." But the main purpose of our papers was to demonstrate that the Fundamental Complex is not an entity and is the equivalent neither of the Scourian Complex nor of the Laxfordian Complex. In our view of the Lewisian, the Fundamental Complex consists of two entirely separate complexes of heterogeneous gneiss which were formed in two definitely separable epochs, largely by metamorphic processes, both essentially similar and characteristically metasomatic. Each complex is of equal standing, both equally " fundamental ". It would, in our opinion, be as accurate and as useful to refer to the Laxfordian as modified or reconstituted Scourian as it would be to refer to a basal conglomerate of the Torridonian as modified Lewisian.

The lines of argument that led us to our conclusions can best be explained by comparing the current views of the Lewisian with our own. In the North-West Highland Memoir, the Fundamental Gneiss Complex is held to be dominantly orthogneiss. On p. 100 of the Memoir, Teall wrote of the later granitic rocks: "The intrusive magma was homogeneous. In this respect there is a marked contrast between the later intrusions and the Fundamental Complex ...". The belief thus grew up that, as the Fundamental Complex consisted largely of variable gneisses, and as no heterogeneous intrusions of later date were known, all the Fundamental Complex must have formed before the Scourie dykes were intruded. A paradox arose when at the same time it was found that the Fundamental Complex, which in some places is cut by dolerite dykes, is in others indistinguishable not only from the altered dolerites but from the even later granitic gneisses.

Once it is granted that the Scourian complex was formed by metasomatism and recrystallization of a series of pre-existing materials, and when it is appreciated that in Laxfordian times similar metasomatism and recrystallization took place, it then becomes possible to advance a new solution for this problem. We discovered at Torridon and Scourie that the well-known movements and granitic injections of the Laxfordian period had been accompanied by widespread metasomatism. The metasomatic changes that took place were so great that the Laxfordian biotite and hornblende gneisses produced by them are, in our opinion, virtually new rocks. Because they were formed by similar processes, the gneisses of the Laxfordian and Scourian complexes resemble each other, but this similarity should not be taken as a demonstration of their identity.

We propose that the Fundamental Complex should be divided into two parts. In the Scourian complex we place all the rocks produced during the Scourian metamorphism, irrespective of the age of the material from which they were formed. In the Laxfordian complex we place all the rocks produced during the Laxfordian metamorphism, irrespective of the age of the material from which they were produced. The latter complex includes the Laxfordian granite gneisses and the altered Scourie dykes, about whose age there has never been any doubt, together with the second generation of heterogeneous gneisses, hitherto held to be part of the Fundamental Complex, which in the field are of ten inseparable from the granitic rocks. Neither Scourian nor Laxfordian complex, by itself, is equivalent to the Fundamental Complex.

The classification adopted by us and the current classification are given below :-

Current Classification.

3. Acid intrusions

2. Scourie dykes

1. Fundamental complex (Bailey's "Assynt complex ")
Sutton and Watson.

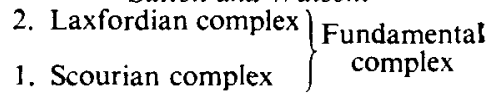

(N.B.-Bailey has erroneously identified our Scourian complex with the Fundamental Complex.) 
In post-Cambrian times, periods of such extensive migmatization and metamorphism as those which we believe to have produced the Scourian and Laxfordian complexes are usually connected with orogeny, and in our paper we consider the possibility that the Scourian and Laxfordian periods may have been orogenic. If this is so, then each complex, with its welldefined structural pattern, is a fragment of a separate orogenic belt, an interpretation not hinted at in Sir Edward Bailey's address to the XVIII International Greological Congress on the Structural History of Scotland (General Proceedings, XVIII Int. Geol. Congr., Part I, p. 230). Three orogenic periods might thus be represented in the North-West Highlands; the Scourian, the Laxfordian, and the Caledonian.

In conclusion, we would ask any readers interested in the questions raised here to suspend judgment until our paper has appeared, and to remember that Sir Edward Bailey's comments to date are based upon so great a misconception that he unwittingly attributes to us the very view of the Lewisian that we are actually seeking to disprove.

\section{DePARTMENT OF GEOLOGy, IMPERIAL COLLEGE, LONDON, S.W. 7.

SIR, - I have read with regret, tinged I may add with some surprise, the latest example of intolerance coming from the pen of Sir Edward Bailey, and appearing in the May-June number of the Geological Magazine. That he should regard himself as the sole champion of the giants of Highland geology and the custodian of the final revelation of the geology of the Northwest as established in the Survey Memoir of 1907, is one of those personal foibles which I pass over without comment.

I need not consider at length his reflections on my own shortcomings, being all too conscious of the fact that I, like many others, am groping towards the truth, and have not yet attained that blissful certainty which appears to be his prerogative. In our own humble ways, my students and I are trying to carry on the tradition of those who have gone before. To us, as to them, no views are sacrosanct, and we will continue to test all opinions in the light of the facts as they become known.

It may of course be true that I am not as deeply read in Highland geology as Sir Edward, and have consequently misled my students, but I would add that at least $I$ have not committed the error of launching into a detailed criticism of a paper which I have neither read nor heard, a preliminary that Sir Edward appears to have neglected in his latest outburst.

Imperial College of Science and Techiology, H. H. READ. LONDON, S.W. 7. 6th July, 1951 .

SrR,-Thanks to the courtesy of the authors I have been given an opportunity of reading the above, but it has in no way affected my understanding of the geology of the case. It seems to me clear that what the authors have called Scourian Complex (whatever its pre-Scourie-Dyke history) is synonymous with the Fundamental Complex of the North-West Highland Memoir.

I should like to draw attention to a correction received by post from Kennedy. It concerns the term "Assyntian", which I had suggested might be substituted for the authors' "Scourian", to avoid clashing with the Scourie Dykes. Kennedy points out that "Assyntian " is itself preoccupied, since Stille has used it to denote a supposedly world-wide orogeny-somewhere in age between Torridonian and Cambrian. This affords an amusing 
example of a biter bitten. I now humbly put forward "Inverian" (with accent on the ver). Coastal exposures at Loch Inver have long been regarded as typical of the Assynt district. The Stille reference is : 1946. Die Assyntische Ana und der vormit- und nach Assyntische Magmatismus. Zeits. deutsch. Geol. Gesell., xcviii, 152.

19 Greenhill Gardens,

E. B. Bailey.

EDINBURGH.

17th July, 1951.

\section{REVIEWS}

Structural Petrology of Deformed Rocks. By H. W. Fairbairn, with supplementary chapters on Statistical Analysis by F. CHAYES. AddisonWesley Press Inc. (Cambridge, Mass.). 2nd ed., 1949, ix 344 pp., price $\$ 12.50$.

This book is an expansion of the first edition (1941); the more recent work has been incorporated and an additional section added on statistical analysis. The book falls into three main parts (i) Petrotabric and Experimental Facts, (ii) Interpretation and Application, (iii) Methods and Analytical Procedures, including Statistical Methods. It is by far the best book on structural petrology (petrofabrics) in the English language. The material is presented in a lucid and concise style, with a wealth of clear diagrams, and an admirably objective assessment of differences in interpretation and theory. The references to the literature are comprehensive and are especially valuable to those approaching the subject for the first time ; for though Dr. Fairbairn makes no claim that this is a textbook, an intelligent honours student, by reading the text and consulting the references appropriate to those portions he finds too condensed, will obtain an excellent appreciation of the subject. It is therefore all the more to be regretted that the price puts the book into that group which is only consulted in the library.

\section{S. O. A.}

Coal Mining. By I. C. F. Statham. pp. xi +564 , with 310 figs. English Universities Press, Ltd., London. 1951. Price 22s. 6 d.

This excellently printed and profusely illustrated book on the applied science of coal-mining has the stamp of authority which one would expect from the eminent position held in the mining world by its author. The geologist who reads it with the idea of obtaining a comprehensive picture of the exploitation of Britain's greatest mineral asset will find a wide variety of subjects to interest him. There are chapters dealing with the purely human questions of safety, health, welfare, training, and organization, others describing the engineering problems of surface plant, underground transport, ventilation, and lighting, and still others upon such questions as methods of coal-winning, roof support, and draining where the geological reader will have more than a detached interest. It is only when he reads the chapter on the origin of coal that the geologist will be disappointed, for there is no doubt that the author, in attempting to simplify the petrology and stratigraphy of coal to a point where it can be understood by all practical miners, has oversimplified to the verge of inaccuracy. A few examples of this sort may be quoted - the mention of Kimmeridge "Coal" as if it were no different from a bituminous coal ; the omission of any reference to pteridosperms except as ferns, and the description of the geological background to the discovery of the Kent coalfield. Occasionally a statement occurs which is palpably wrong-such, for instance, as "the average hade of faults in the coal measures is about $60^{\circ} "$. The diagrammatic illustrations to the geological section are in the main excellent but there are three exceptions 